\title{
The Relationship between Risk taking and Self-assessment of EFL Learners in Writing Ability
}

\author{
Yabancı Dil Olarak EFL İngilizce Öğrencilerin Yazma Becerilerinde Risk \\ Alma ve Kendini Değgerlendirme Arasındaki İlişki
}

\begin{abstract}
Ali Akbar FARAHANI* Zeinab HIVECHI*

Abstract: The present study investigates the relationship between risk-taking and self-assessment of EFL learners in writing ability. To this end, 31 Iranian senior students completed a risk-taking questionnaire based upon the Venturesomeness subscale of Eysenck's IVE modified by Kiany and Pournia (2006), to rate their risk-taking levels. Based on their answers, the students were divided into two groups: high risktakers and low risk-takers. They were then given a topic about which to write an essay and also to assess their writing skills. Two intra-raters were chosen to rate the students' writings based on just the correct structure of essay writing, not grammar or word correction or other details since the aim of study was to investigate students' risk-taking in their academic life in comparison to their social life. To analyse the obtained data, Pearson Correlation Coefficient and Multi-variance Analysis of Variance (MANOVA) were used as statistical procedures. The results did not show any significant relationship between risktaking and students' self-assessment in writing. In other words, the high risk-takers and low risk-takers were the same in assessing their writings. Also high risk-takers did not show any risks in their writings, such as using complicated sentences, new structures, and so forth. The implications of the study are further discussed.
\end{abstract}

Keywords: Assessment, essay writing, risk-taking, self-assessment

Özet: $\mathrm{Bu}$ çalışma yabancı dil olarak EFL ingilizce öğrencilerin yazma becerilerinde risk alma ve kendini değerlendirme arasındaki ilişkiyi incelemektedir. Sonunda 31 lise öğrencisi Kiany ve Pournia (2006) geliştirmiş olduğu Eysenck'in girişkenlik ölçeğine göre hazırlanmış risk alma anketini doldururlar. Yanıtlara göre öğrenciler, yüksek risk alıcılar ve az risk alıcılar olmak üzere iki gruba ayrıldı. Onlara bir deneme yazmaları ve de kendi yazım becerilerini değerlendirmek için bir konu başlığı verildi. Öğrencilerin yazılarını sadece doğru cümle kurulumunu değerlendiren iki ölçücü seçildi. Bu çalışmanın amacı öğrencilerin akademik hayatıyla sosyal yaşamda risk olmalarını incelediği için, öğrencilerin dilbilgisi, kelime bilgisi ya da diğer dil becerileri değerlendirilmemiştir. Elde edilen verileri değerlendirmek için, istatistik işlemleri olarak Pearson Correlation Coefficient ve Variance'ın çoklu analizi MANOVA kullanılmıştır. Sonuçlar risk alma ve kendini değerlendirme arasında önemli bir ilişki olmadığını gösterdi. Diğer bir deyişle, yüksek risk alıcılar ve az risk alıcılar kendi yazılarını değerlendirmede benzerdi. Çok risk alıcılar yazılarında birleşik cümle, yeni yapı ve diğerlerinin kullanımı gibi alanlarda herhangi risk göstermemiştir. Araştırmanın sonuçları metinde detaylı tartışılmaktadır.

Anahtar sözcükler: Değerlendirme, deneme yazma, risk alma, kendini değerlendirme

\footnotetext{
* Assist. Prof., University of Tehran, English Department, Tehran, s.khezrlou@gmail.com

** MA, University of Tehran, English Department, Tehran.
} 


\section{INTRODUCTION}

Recent years have observed a shift in the focus of assessment from the traditional standardized methods of testing, such as multiple choice tests to non-traditional types of assessment. There has been growing attention paid to these non-traditional methods of assessment which have come to be known as alternative assessments including: performance assessment, portfolio assessments, student self-assessments, peer assessments, and so forth (e.g., Herman, Aschbacher, \& Winters, 1992; Huerta-Mac'1as, 1995).

As one form of alternative assessment, self assessment as one measure of students' language competencies has attracted attention in language education. In its broadest sense, self-assessment in writing signifies all teaching methods that prompt writers to think about, evaluate, and/or respond to their own writing. Through this process of self-evaluation, the writer both improves the finished written product and builds a repository of writing and revising skills for later use. Self-assessment methods include any number of exercises intended to encourage reflection in order to foster improvement. Self-assessment has received growing attention in the literature of both composition and literacy studies. Self-assessment in particular and alternative assessment in general have been advocated by the literature based upon Graham and Harris's (1993) self-regulated strategy development model (SRSD).

\subsection{Self-Assessment: Theoretical Framework}

Self-assessment is a practice grounded in several principles of learning theory. Many studies use such concepts as the basis for arguments about its promise in the teaching of writing. Many publications included in this discussion are based on observation and the description of classroom effects or action research; a small number incorporate the collection of data to support conclusions. Very few studies of effectiveness can be found in the literature to date. To test the many theories of the effect of self-assessment on student writing outcomes, additional studies of self-assessment practices using experimental methods should be conducted in future research.

It is argued first that self-assessment is supportive of metacognition, requiring writers to reflect on their own writing, their process of writing and revising, and their changes, improvement, or continued needs in writing (Falchikov, \& Boud, 1989; Campillo, 2006; Bardine, \& Fulton, 2008). Murray (1982) describes the process of writing and revising as a conversation with the writer's self. In this sense, writing requires continual metacognition, as writers must learn to assess and evaluate their own ideas and expression objectively in order to make continual improvements to writing tasks and to further develop as a writer. The author suggests that self-assessment prompts this kind of internal dialogue. The concept of transfer is discussed frequently in the literature as a desired outcome of the teaching of writing (Elbow, \& Belanoff, 1995; Orsmond, et alii, 2004; Campillo, 2006; Nicol, \& Macfarlane-Dick, 2006). For educators, it is hoped that students leave writing courses with not only a strong finished writing product for the course, but also a transferable set of writing skills for future needs. However, even when teacher support and substantial feedback are provided in abundance, writers are still working, in essence, in isolation; as crafting an essay is a solitary, personal, and individual endeavor. Writers must move from the internal formulation of ideas to the drafting stages, and they must learn how to follow such a process or progression for future success in writing. Educators have devised self-assessment exercises, in part, as a means to foster learning and the transfer of such writing skills. In addition, it is frequently argued that self-assessment encourages the types of learner autonomy required for successful writing -- within the writing class and in future work (Boud, \& Falchikov, 1989; Vickers, \& Ene, 2006; Bardine, \& Fulton, 2008) It is difficult to test the theory that self-assessment leads to greater learner autonomy, and no studies currently 
undertake such a task, but many descriptive publications express a sense, based on observation, that students become more independent through the use self-assessment exercises (Vickers, \& Ene, 2006; Bardine, \& Fulton, 2008).

Chanquoy and Alamargot (2002) proposed a unique argument in favor of the development of expertise in writing through metacognition and learner autonomy. The authors applied the concept of working memory in writing (Hayes, 1996; Kellogg, 1996) to the development of the writing skill. They posit that, because working memory is taxed in writing, it is important for writers to build a stock of knowledge of writing steps, strategies, and processes in their longterm memory; in other words, they should surpass the novice level of understanding of writing and move toward the expert phase (Bransford, et alii, 2000; Sommers, \& Saltz, 2004). They suggest that self-assessment methods encourage exactly the sort of autonomous mastery of writing strategies needed to overcome the limitations of working memory and to improve as a writer.

A final perceived benefit of self-assessment method hails from the popular notion in composition theory of supporting an authentic sense of student voice in writing (Elbow, 1994; Stewart, 1972). Numerous publications in writing and rhetoric theory, over the past two decades in particular, have explored the importance of enabling the expression of student voice by providing a sense of purpose and meaning, as well as motivation for the writer (Diltz, 2006; Yancey, 1998). Diltz supports the use of several types of reflective exercises in writing, with a particular emphasis on the writers' holistic evaluation of drafts in order to help students "activate" their voices. She describes the struggle faced by many educators to stimulate student interest in writing and to encourage learners to move beyond fact and regurgitation to the generating of original ideas that are uniquely individual. She proposes self-assessment methods that may foster creative and analytical processes in writing.

\subsection{Self-assessment and Writing Skill}

Since the appearance of the first two important studies (Boud, \& Falchikov, 1989; Falchikov \& Boud, 1989), self- assessment has attracted attention in a growing number of disciplines where writing is taught and evaluated. The implementation of self-assessment practices has expanded from the more rigid model of SRSD strategies, as well as from the very broad open-ended response to writing introduced in composition literature, to incorporate support for a number of activities targeting more specific skills in writing. Self-assessment is frequently posited as an alternative or a complement to peer evaluation that might be used to supplement instructor guidance. In several recent publications, self-assessment has been found by instructors to be a way to encourage the development of metacognition (Campillo, 2006; Andrade, \& Valtcheva, 2009) and growth in writing among beginning writers who may have trouble reviewing their own work to make improvements (McCarthy, Meier, \& Rinderer, 1985; Bloom, 1997; Nicol, \& Macfarlane-Dick, 2006; Graziano, \& King, 2007).

If the purpose of instruction and assessment is meaningful learning, learning has to be about constructing knowledge rather than acquisition of knowledge (Mayer \& Moreno, 2003). The last decade has witnessed a widespread experimentation with learner-centered alternative assessment methods. The concern of assessment is now the ongoing assessment of students' efforts and contribution to the learning process (Ross, 2005). Assessment is viewed as a dynamic, ongoing process which is inextricably linked to teaching and learning. In fact, in the constructivist education, assessment occurs simultaneously with the learning process (Marlowe, \& Page, 2005).

Self-assessment becomes even more important in the evaluation of students' writing performance. Assessment is a popular and sometimes misunderstood term in current educational prac- 
tice (Brown, 2004). Not many centuries ago, writing was a skill that was highly ignored and considered to be a part of grammar learning and translation. Today, however, the ability to write has become an indispensable skill in our global literate community. Every educated child in developed countries learns the rudiments of writing in his or her native language, but very few learn to express themselves clearly with logical, well-developed organization that accomplishes an intended purpose. We expect second language learners to write coherent essay with artfully chosen rhetorical and discourse devices (ibid). The assessment of writing is not a simple task.

\subsection{Risk-taking and Self-assessment}

Risk-taking is defined in the dictionary of language teaching and applied linguistics as " $a$ personality factor which concerns the degree to which a person is willing to undertake actions that involve a significant degree of risk" (Richards, Platt, \& Platt, 1992, 317). Also, Brown (2001) mentioned that self-confidence and language ego lay the ground work for risk-taking. As mentioned in Wen and Clement (2003), good language learners are supposed to be risk-takers. They are willing to guess, willing to appear foolish, to be risk-takers and willing to try out new structures about which they are unsure. Risk taking is shown to be related to success in language learning. Ely (1986) for instance, assumed that high risk-taking will yield positive results in second language learning. Also, Evensen and Bednar's study (as cited in Jonassen \& Grabowsky, 1993) showed that high risk-takers reported greater perceived depth of communication. Ely (1986) believed that language class risk-taking involves a tolerance of possible incorrectness while using the language. Reiss (1985), after measuring tolerance of ambiguity with three situation-specific items, found a positive relationship between tolerance of ambiguity and university foreign language students' ratings of themselves as language learners. Using the language class risk-taking scale (a 6-item measure developed by Ely 1986), Liu and Jackson (2008) found that there was a significant and positive relationship between language class risktaking and students' self-rated proficiency in English reading, writing, listening, speaking and the overall English language proficiency. The more risk-taker the student was, the higher the self-reported ratings in listening, reading, writing and speaking were, with the speaking ability being the most positively correlated to language class risk-taking.

"Learners have to be able to gamble a bit, to be willing to try out hunches about the language and take the risk of being wrong" (Brown, 2001, 149). Thus, risk-taking was included in the study to see whether it has any role in self-assessment and to what extent students can make intelligent guesses about their writing ability.

The present study was conducted in order to find out whether there was any relationship between risk-taking and learners' self-assessment in writing skill. This study was also an attempt to investigate different raters' assessments of the students' writing abilities. In the present study, the following research question was included: 1 . Is there any significant relationship between risk-taking and learners' self-assessment in writing ability?

\section{METHOD}

\subsection{Participants}

The participants of the study included 31 undergraduate EFL students at the Islamic Azad University of Gorgan who were majoring in English language teaching (ELT). They were senior students who had passed general courses like reading comprehension, conversation, and grammar. They had also passed a course on paragraph writing. They were given a risk-taking questionnaire, to determine the degree of each student's risk-taking level in social life, then a topic was 
considered for writing an essay about it, to relate their academic writing to the students questionnaire answer, and to see if these two papers are related, if there is a positive or a negative relation. The purpose being to examine if the risk-taker students took risk in their writing or not.

\subsection{Instrumentation}

To collect the data for this study and in order to measure different variables under investigation, the following instruments were employed: the Venturesomeness subscale of Eysenck's IVE questionnaire and a writing task.

2.2.1. The Venturesomeness subscale of Eysenck's IVE questionnaire validated by Kiany and Pournia (2006) has been used in order to determine the participants' levels of risk-taking, and based on the students' answers to the questionnaire, the participants were divided into two groups, risk-takers and non-risk takers.

2.2.2. A writing task was given to illustrate writing samples and the researcher wanted to see if students would take risk in their writing and also how they could assess their writing. They were given 30 minutes to write an essay and after they finished their writing, they were requested to assess their writing based on one of our four-point Likert scale of writing skills.

\subsubsection{Research Design}

The design of this study is an ex-post-facto design, for the following reasons: the present study did not examine a causal relationship between the variables, there was no instructional treatment to bring about a change, there was no random selection of the subjects, nor was there a control group, and the researcher did not have control over the variables. According to Hatch and Farhady $(1982,26)$, "ex post facto designs are used when the researcher does not have control over the selection and manipulation of the independent variable".

\subsection{Procedure}

31 undergraduate EFL students were given the Venturesomeness subscale of Eysenck's IVE questionnaire to investigate their level of risk-taking in their social life. The second step was to give them a topic to write an essay and request them to assess their writing based on Likert fourpoint scale. Students should also have paid attention to the first and primary part of writing essay structure, the development of the thesis statement, body paragraphs and conclusion, outlining, coherence, and unity and assessment of their writing. Since the participants were senior students of TEFL and they had passed all important parts of writing structures, it was deemed that they had the ability to accomplish all these aspects in their writing. The researcher didn't attend to the grammatical structure and syntactic complexity. Two intra-raters were chosen to assess students writing to ascertain the inter-reliablity of the assessment.

\subsection{Data Analysis}

Quantitative analysis method was used to analyze the data including a Pearson Correlation Coefficient and a Multivariate Analysis of Variance (MANOVA) to see the possible impact of risk taking on the self-assessment in writing.

\section{RESULTS}

To achieve the objectives of this study, the following statistical procedures were conducted. Firstly, a Pearson Correlation Coefficient was used to investigate the relationship between risktaking and learners' self-assessment in writing ability. In addition, a Multivariate Analysis of Variance (MANOVA) was deployed to see the differences between risk takers and non-risk 
takers with regard to their writing ability. Results of data analysis unraveled the following.

To find the answer to the research question of the study, a Pearson Correlation Coefficient was used. Results are presented in tables 4.1 and 4.2 below. Table 4.1 shows the relationship between the students' self-assessment of their writings and their risk taking. Table 4.2 signifies the relationship between the students' risk taking and the raters' assessment of their writing ability.

Table 4.1. The Relationship between the Students' Writing Assessment and their Risk taking

\begin{tabular}{|c|c|c|c|}
\hline \multirow{3}{*}{ Risk taking } & Pearson Correlation & 1 & .242 \\
& Sig. (2-tailed) & & .198 \\
\cline { 2 - 4 } & $\mathrm{N}$ & 31 & 30 \\
\hline \multirow{3}{*}{ Assessment } & Pearson Correlation & .242 & 1 \\
\cline { 2 - 4 } & Sig. (2-tailed) & .198 & \\
\cline { 2 - 4 } & $\mathrm{N}$ & 30 & 30 \\
\hline
\end{tabular}

Correlation is significant at the 0.01 level (2-tailed)

As can be seen, the correlation between the risk taking and the students' self-assessment of their writing $(\mathrm{r}=0.242)$ is not significant at 0.01 level $(\mathrm{p}=0.198>0.01)$. The results of the analysis show that there is a week, positive and non-significant relationship between the two variables of the study. This is to say that the writing performance of the learners is not related to their risk taking capacity.

Table 4.2 below shows the results of correlation coefficient for the raters' assessment and the students' risk taking capacities.

Table 4.2. The Relationship between the Raters' Writing Assessment and their Risk taking

\begin{tabular}{|c|c|c|c|}
\hline \multicolumn{2}{|c|}{} & Risk taking & Raters' assessment \\
\hline \multirow{3}{*}{ Risk taking } & Pearson Correlation & 1 & -.156 \\
& Sig. (2-tailed) & & .402 \\
\cline { 2 - 4 } & $\mathrm{N}$ & 31 & 31 \\
\hline \multirow{2}{*}{$\begin{array}{c}\text { Raters' } \\
\text { assessment }\end{array}$} & Pearson Correlation & -.156 & 1 \\
\cline { 2 - 4 } & Sig. (2-tailed) & .402 & 31 \\
\cline { 2 - 4 } & $\mathrm{N}$ & 31 & \\
\hline
\end{tabular}

Correlation is significant at the 0.01 level (2-tailed)

The results of Table 4.2 indicate that there is a week, negative, and non-significant correlation between the raters' assessment and students' risk taking.

In addition to the above statistical analyses, a multivariate analysis of variance (MANOVA) was conducted to see if risk taking had any significant impact upon the students' self-assessment and the raters' assessment. Three statistical tests were performed to examine whether the statistical assumptions underlying the use of Multivariate Analysis of Variance (MANOVA) were violated in the data set. First, Box's M test of equality of covariance matrices indicated that there were no significant differences between the covariance matrices. Therefore, the assumption of homogeneity of covariances across groups was not violated. Secondly, Levene's 
test of equality of error variances indicated that the homogeneity of variance for each of the dependent measures was not violated in the data set $(p>0.05)$. The third test used was the multivariate test of significance, Wilks' Lambda criterion variance which indicated that there was a statistically significant multivariate effect for risk levels $(\mathrm{F}=2.812, \mathrm{p}<0.05)$. Having determined that the results met the statistical criteria set out above, the next step was to conduct MANOVA. Firstly, the results of descriptive statistics are reported in table 4.3 which show the means and standard errors for the self-assessment and rater assessment of risk taking and nonrisk taking participants of the study.

Table 4.3. Descriptive Statistics for the Impact of Risk taking on the Students' Writing Performance

\begin{tabular}{|c|c|c|c|c|c|}
\hline \multirow{2}{*}{ Dependent Variable } & risk & Mean & \multirow{2}{*}{ Std. Error } & \multicolumn{2}{|c|}{$95 \%$ Confidence Interval } \\
& & & & Lower Bound & Upper Bound \\
\hline \multirow{2}{*}{ Self-assessment } & risk taker & 3.429 & .178 & 3.064 & 3.793 \\
& non-risk taker & 3.750 & .167 & 3.409 & 4.091 \\
\hline \multirow{2}{*}{ Raters } & risk taker & 3.929 & .093 & 3.739 & 4.118 \\
\cline { 2 - 6 } & non-risk taker & 3.812 & .087 & 3.635 & 3.990 \\
\hline
\end{tabular}

As the results in the above table show, there were no differences in the mean scores of risk taking and non-risk taking students with regard to their assessments and those of raters. However, in order to reach more accurate findings, MANOVA was conducted, the results of which are shown in table 4.4.

Table 4.4. Tests of Between-Subjects Effects for the Impact of Risk taking on the Students' Writing Performance

\begin{tabular}{|c|c|c|c|c|c|c|c|}
\hline Source & $\begin{array}{l}\text { Dependent } \\
\text { Variable }\end{array}$ & $\begin{array}{l}\text { Type III } \\
\text { Sum of } \\
\text { Squares }\end{array}$ & $d f$ & $\begin{array}{l}\text { Mean } \\
\text { Square }\end{array}$ & $\mathrm{F}$ & Sig. & $\begin{array}{c}\text { Partial Eta } \\
\text { Squared }\end{array}$ \\
\hline \multirow{2}{*}{$\begin{array}{c}\text { Corrected } \\
\text { Model }\end{array}$} & Self-assessment & $.771^{\mathrm{a}}$ & 1 & .771 & 1.738 & .198 & .058 \\
\hline & Raters & $.101^{\mathrm{b}}$ & 1 & .101 & .837 & .368 & .029 \\
\hline \multirow{2}{*}{ Intercept } & Self-assessment & 384.771 & 1 & 384.771 & 866.841 & .000 & .969 \\
\hline & Raters & 447.434 & 1 & 447.434 & 3.7223 & .000 & .993 \\
\hline \multirow{2}{*}{ Risk taking } & Self-assessment & .771 & 1 & .771 & 1.738 & .198 & .058 \\
\hline & Raters & .101 & 1 & .101 & .837 & .368 & .029 \\
\hline \multirow{2}{*}{ Error } & Self-assessment & 12.429 & 28 & .444 & & & \\
\hline & Raters & 3.366 & 28 & .120 & & & \\
\hline \multirow{2}{*}{ Total } & Self-assessment & 402.000 & 30 & & & & \\
\hline & Raters & 452.000 & 30 & & & & \\
\hline \multirow{2}{*}{$\begin{array}{c}\text { Corrected } \\
\text { Total }\end{array}$} & Self-assessment & 13.200 & 29 & & & & \\
\hline & Raters & 3.467 & 29 & & & & \\
\hline
\end{tabular}

a. $\mathrm{R}$ Squared $=.058$ (Adjusted R Squared $=.025)$

b. R Squared $=.029$ (Adjusted R Squared $=-.006$ )

As the results of table 4.3 show, the risk taking variable of the study did not have a significant impact $(\mathrm{F}=1.73$, Sig. $=0.198)$ upon the students' self-assessment of their writings. In other 
words, there have been no significant differences between risk taking and non-risk taking students' self-assessment scores. The results were the same for the effect of risk taking on the raters' assessment such that there were no significant differences between risk taking and nonrisk taking students $(\mathrm{F}=0.83$, Sig.= 0.36$)$ when their writings were evaluated by the raters.

\section{Conclusion and Discussion}

The result of the quantitative data analysis showed that risk-taking and subjects' self-assessment in their writing did not have any significant relationship, the findings indicated that students tried to separate their social and their academic life; they did not consider these two sides related to each other. Self assessment is a practice grounded in several principles of learning theory. Many studies use such concepts as the basis for arguments about its promise in the teaching of writing. Many publications included in this discussion are based on observation and description of classroom effects or action research; a small number incorporate the collection of data to support conclusions. Very few studies of effectiveness can be found in the literature to date. To test the many theories of the effect of self assessment in students' writing outcomes, additional studies of self-assessment practices using experimental methods should be conducted in future research.

According to Jonassen and Grabowski (1993), risk-takers are process-oriented and have more tolerance for errors than cautious people. In addition to these characteristics, risk-takers are said to be process-oriented, to have high tolerance for errors, and like to try out new things, whereas cautious people are said to be process-oriented, to possess low tolerance for errors, and to be impatient with trial-and-error. In other words, risk-takers tend to use more complex structures in their production, and tend to accept more errors; consequently, they have a tendency to be less accurate in their productive skills (Kiany, \& Pournia, 2006). These arguments are in line with the finding of the present study in which risk-takers could not tolerate the ambiguity of self-assessment and proved to be more inclined towards the provision of feedback and evaluation from the teacher.

In a study of Clifford and Chou (1991) it was found that both variable pay-off and game context increased the level of academic risk-taking. Moghadasian-Rad (1994) found that risk level of EFL language learners did affect their grades in reading comprehension. Kiany and Pournia (2006) found that there was no significant relationship between risk-taking and syntactic complexity and grammatical accuracy in both writing tasks (ibid). Although advocated by Oscarson (1989) and Ellis (2003), self-assessment procedures have been questioned by different scholars and the accuracy associated with the procedures has been questioned by some scholars. In a study, Ross (1998) signifies that the degree of experience learners bring to the self-assessment context influences the accuracy of the product. The study suggests that there may be a weak evidence of construct validity for self-assessment procedures when there is a mismatch between the content of the self-assessment items and criterion skills. This fact underscores the point that self-assessment procedures must reflect the skills identified in the curriculum so that the content validity is assured and which in turn indicates a high predictive validity. Ross (1998) illustrates that the accuracy of self-assessment with the reading skill is higher than the accuracy of lesser developed skills due to the fact that the learners in EFL situations gain more experience with the written word than with speaking or listening skills. Blanche and Merino (1989) support Krashen's Monitor Model and suggest that learners' selfevaluation is largely affected by the use of the monitor. Nevertheless the extent to which monitoring and self-assessment can be used by learners according to Blanche and Merino, depends on the type of task, in the sense that those that ask learners to focus on linguistic 
content invite monitoring, more than those requiring learners to focus on communication. Heilenman (1990) has found that self-assessment procedures are dependent on the response effects. Heilenman defines the response effects as the tendencies for certain people to respond to factors other than question content. Such factors, according to Heilenman, include acquiescence (a tendency to respond positively), social desirability (a tendency to respond so as to appear to conform to perceived social values), question wording effects, and context effects. AlFallay (2004) has investigated the relationship between some psychological and personality traits and the accuracy of self-assessment and peer-assessment of oral presentation tasks. Students with low self-esteem rated their oral ability more accurately than those with higher self-esteem. The study suggests that students with low motivation intensity perform better than those with high motivational intensity and the least accurate group are the learners of instrumental orientation. The results of the study indicate that self-assessment and peer-assessment are valid measurement instruments based on the high correlations between teacher-assessment, self-assessment, and peer-assessment. The results of the study carried out by Bachman and Palmer (1989) indicate that self-ratings can be reliable and valid measures of communicative language abilities. It has been found that different question types would prove equally reliable and valid, that is, the two measures prove to be reasonably good indicators of the specific language abilities. 


\section{REFERENCES}

AlFallay, I. (2004). "The Role of Some Selected Psychological and Personality Traits of the Rater in the Accuracy of Self- and Peer-Assessment”. System, 32, 407-425.

Andrade, H., \& Valtcheva, A. (2009). "Promoting Learning and Achievement Through Self-Assessment". Theory into Practice, 48, 1, 12-19.

Bloom, L. Z. (1997). "Why I (used to) Hate to Give Grades". College Composition and Communication, 48, 3, 360-371.

Bachman, L. F., \& Palmer, A. S. (1996). Language Testing in Practice. Oxford: Oxford University Press.

Bardine, F., \& Fulton, P. (2008). "Analyzing the Benefits of Revision Memos During the Writing and Revision Process". The Clearing House, 81, 4, 149-54.

Blanche, P., \& Merino, B. J. (1989). "Self-Assessment of Foreign-Language Skills: Implications for Teachers and Researchers". Language Learning, 39, 313-340.

Bransford, J. D., Brown, A. L., \& Cocking, R. R. (2000). How People Learn. Washington, D.C., National Academy Press.

Brown, H. D. (2001). Teaching by principles: An Interactive Approach to Language Pedagogy. New York: Longman.

Brown, H. D. (2004). Language Assessment: Principles and Classroom Practices. White Plains, New York: Longman.

Boud, D., \& Falchikov, N. (1989). "Quantitative Studies of Student Self-Assessment in Higher Education: A Critical Analysis of Findings". Higher Education, 18 (5), 529-549.

Campillo, M. (2006). “Acquisition and Transfer of a Writing Revision Strategy: A Self-Regulatory Analysis". The Humanities and Social Sciences, 17, 32-45.

Chanquoy, L., \& Alamargot, D. (2002). "Working memory and writing: Model evolution and research assessment (In French)". In L'Année Psychologique, 102.

Clifford, M. M., \& Chou, F. (1991). Effects of payoff and task context on academic risk taking. Journal of Educational Psychology, 83, 499-507.

Diltz, J. (2006). "Words to voice: Three Approaches for Student Self Evaluation”. Teaching English in the Two-Year College, 34, 1, 41-45.

Elbow, P. (1994). “About Voice and Writing”. In P. Elbow (Ed.) Landmark essays on voice and Writing 146-157. NJ: Hermagoras Press.

Elbow, P., \& Belanoff, P. (1995). A Community of Writers: A Workshop Course in Writing. New York: McGraw-Hill.

Ellis, R. (2003). Task-Based Language Learning and Teaching. New York: Oxford.

Ely, C. M. (1986). “An Analysis of Discomfort, Risk-Taking, Sociability, and Motivation in the L2 Classroom". Language Learning, 36 (1), 1-25.

Falchikov, N. (1986). "Product Comparisons and Process Benefits of Collaborative Peer Group and SelfAssessment”. Assessment \& Evaluation in Higher Education, 11, 146-166.

Graham, S., \& Harris, K. R. (1993). "Self-Regulated Strategy Development: Helping Students with Learning Problems Develop as Writers”. Elementary School Journal, 94, 169-181.

Graziano-King, J. (2007). Assessing Student Writing: The self-revised essay. Journal of Basic Writing, $26(2), 73-92$.

Hatch, E. \& Farhady, H. (1982). Research Design and Statistics for Applied Linguistics. Rowley, MA: Newbury House.

Rowley: Newbury House Publishers. Hayes, J. R. (1996). A New Framework for Understanding Cognition and Affect in Writing. In C. M. Levy, \& S. Ransdell (Eds.), The Science of Writing: Theories, Methods, Individual Differences, and Applications, 1-27. Mahwah, NJ: Lawrence Erlbaum.

Heilenman, L. K. (1990). "Self-Assessment of Second Language Ability: The Role of Response Effects". Language Testing, 7, 174-201.

Herman, L. J., Aschbacher, P. R., \& Winters, L. (1992). A Practical Guide to Alternative Assessment. 
Alexandria, VA: Association for Supervision and Curriculum Development.

Huerta-Mac'ias, A. (1995). "Alternative Assessment: Responses to Commonly Asked Guestions". TESOL Journal, 5, 8-11.

Jonassen, D. H., \& Grabowsky, B. L. (1993). Handbook of Individual Differences, Learning and Instruction. Hillsdale, NJ: Lawrence Erlbaum Associates.

Kellogg, R. T. (1996). "A Model of Working Memory in Writing". Eds. C. M. Levy, \& S. E. Ransdell, The science of writing, 57-71. OUP.

Kiany. G. R., \& Pournia, Y. A. (2006). "The Relationship Between Risk-Taking and the Syntactic Complexity and Grammatical Accuracy of the Iranian Intermediate EFL Learners' Descriptive and Expository Writing”. Pazhuhesh-e Zabanha-ye Khareji, 27 (Special issue, English), 143-64.

Liu, M., \& Jackson, J. (2008). “An exploration of Chinese EFL Learners' Unwillingness to Communicate and Foreign Language Anxiety". The Modern Language Journal, 92 (1), 71-86.

Marlowe, B. A., \& Page, M. L. (2005). Creating and Sustaining the Constructivist Classroom. Sage Publisher.

Mayer, R. E., \& Moreno, R. (2003). "Nine Ways to Reduce Cognitive Load in Multimedia Learning". Educational Psychologist, 38, 43-52.

McCarthy, P., Meier, S., \& Rinderer, R. (1985). "Self-Efficacy and Writing: A Different view of SelfEvaluation". College Composition and Communication, 36, 465-471.

Moghadasian-Rad, Z. (1994). The Role of Risk-taking in EFL Reading Comprehension. An Unpublished MA Thesis. Tehran University. Iran.

Murray, D. M. (1982). Learning by Teaching. Montclair, New Jersey: Boynton/Cook.

Nicol, D., \& MacFarlane-Dick, D. (2006). "Formative Assessment and Self-Regulated Learning: A Model and Seven Principles of Good Feedback Practice". Studies in Higher Education, 31, 2, $199-218$.

Orsmond, P., Merry, S., \& Callaghan, A. (2004). "Implementation of a Formative Assessment Model Incorporating Peer and Self Assessment". Innovations in Education and Teaching International, 41, 3, 273-290.

Oscarson, M. (1989). "Self-Assessment of Language Proficiency: Rationale and Applications". Language Testing, 6, 1-13.

Reiss, M. A. (1985). "The good language learner: Another look". The Canadian Modern Language Review, 41, 511-523.

Richards, J. C., Platt, J., \& Platt, H. (1992). Dictionary of Language Teaching and Applied Linguistics. Harlow, Essex: Longman.

Ross, S. (2005). "The Impact of Assessment Method on Foreign Language Proficiency Growth". Applied Linguistics, 26 (3), 317-342.

Sommers, N., \& Saltz, L. (2004). "The novice as expert: Writing the Freshman Year". College Composition and Communication, 56 (1), 124-49.

Stewart, D. C. (1972). The Authentic Voice: A Pre-Writing Approach to Student Writing. Dubuque, Iowa: Brown.

Vickers, C., \& Ene, E. (2006). "Grammatical Accuracy and Learner Autonomy in Advanced Writing". English Language Teaching Journal, 60, 2, 109-116.

Wen, W. P., \& Clement, R. (2003). "A Chinese Conceptualization of Willingness to Communicate in ESL”. Language, Culture and Curriculum, 16 (1), 18-38.

Yancey, K. B. (1998). Reflection in the Writing Classroom. Logan: Utah State University Press. 